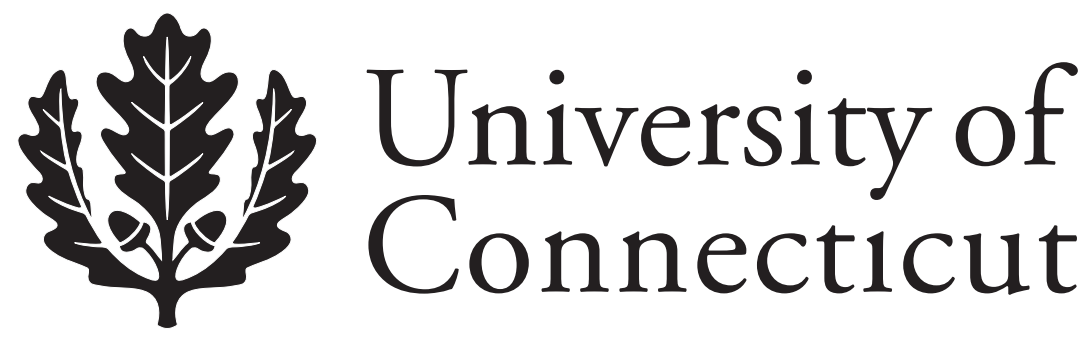

Department of Economics Working Paper Series

\title{
Do Structural Oil-Market Shocks Affect Stock Prices?
}

Nicholas Apergis

University of Piraeus

Stephen M. Miller

University of Connecticut and University of Nevada, Las Vegas

Working Paper 2008-51R

July 2008

341 Mansfield Road, Unit 1063

Storrs, CT 06269-1063

Phone: (860) 486-3022

Fax: (860) 486-4463

http://www.econ.uconn.edu/

This working paper is indexed on RePEc, http://repec.org/ 


\begin{abstract}
This paper investigates how explicit structural shocks that characterize the endogenous character of oil price changes affect stock-market returns in a sample of eight countries - Australia, Canada, France, Germany, Italy, Japan, the United Kingdom, and the United States. For each country, the analysis proceeds in two steps. First, modifying the procedure of Kilian (2008a), we employ a vector errorcorrection or vector autoregressive model to decompose oil-price changes into three components oil-supply shocks, global aggregate-demand shocks, and global oil-demand shocks. The last component relates to specific idiosyncratic features of the oil market, such as changes in the precautionary demand concerning the uncertainty about the availability of future oil supplies. Second, recovering the oilsupply shocks, global aggregate-demand shocks, and global oil-demand shocks from the first analysis, we then employ a vector autoregressive model to determine the effects of these structural shocks on the stock market returns in our sample of eight countries. We find that international stock market returns do not respond in a large way to oil market shocks. That is, the significant effects that exist prove small in magnitude.
\end{abstract}

Journal of Economic Literature Classification: G12, Q43

Keywords: real stock returns; structural oil-price shocks; variance decomposition 


\section{Do Structural Oil-Price Shocks Affect Stock Prices?}

\section{Introduction}

The existing literature contains several attempts to identify the effects of changes in international oil prices on certain macroeconomic variables, such as, real GDP growth rates, inflation, employment, and exchange rates (Hamilton, 1983; Gisser and Goodwin, 1986; Mork, 1989; Hooker, 1996; Davis and Haltiwanger, 2001, Hamilton and Herrera, 2002, Lee and Ni, 2002; Hooker, 2002, among others). Their studies differ from each other with respect to the power of their empirical findings without providing a general consensus.

Fewer research attempts investigate the effects of oil-price changes on asset prices, such as stock prices or stock returns. Market participants want a framework that identifies how oil-price changes affect stock prices or stock market returns. On theoretical grounds, oilprice shocks affect stock market returns or prices through their effect on expected earnings (Jones et al., 2004). The relevant literature includes the following studies. Kaul and Seyhun (1990) and Sadorsky (1999) report a negative effect of oil-price volatility on stock prices. Jones and Kaul (1996) show that international stock prices do react to oil price shocks. Huang et al. (1999) provide evidence in favor of causality effects from oil futures prices to stock prices. More recently, Faff and Brailsford (2000) report that oil-price risk proved equally important to market risk, in the Australian stock market. Hong et al. (2002) also identify a negative association between oil-price returns and stock-market returns. Pollet (2002) and Dreisprong et al. (2003) find that oil-price changes predict stock market returns on a global basis, while Hammoudeh and Li (2004) and Hammoudeh and Eleisa (2004) also discover the importance of the oil factor for stock prices in certain oil-exporting economies. Bittlingmayer (2005) documents that oil-price changes associate with war risk and those associated with other causes exhibit an asymmetric effect on the behavior of stock prices. Sawyer and 
Nandha (2006), however, using a hierarchical model of stock returns, report results against the importance of oil prices on aggregate stock returns, while they retain their explanatory power only on an industrial (sectoral) level. Finally, Gogineni (2007) also provides statistical support for a number of hypotheses, such as oil prices positively associate with stock prices, if oil price shocks reflect changes in aggregate demand, but negatively associate with stock prices, if they reflect changes in supply. Moreover, stock prices respond asymmetrically to changes in oil prices.

Recently, however, researchers began asking whether changes in macroeconomic variables cause oil price changes, leading to the decomposition of those oil price changes into the structural shocks hidden behind such changes (Kilian, 2008a; Kilian and Park, 2007). That is, different sources of oil price changes may imply non-uniform effects on certain macroeconomic variables. More specifically, the relevant literature generates mixed views regarding the effect of such oil-price shocks on asset prices, such as stock prices. Chen et al. (1986) argue that oil prices do not affect the trend of stock prices, while Jones and Kaul (1996) present evidence that favors a negative association. This negative relationship, however, does not receive support by Huang et al. (1996) and Wei (2003).

Kilian (2008a) criticizes all these analyses, because researchers treat oil-price shocks as exogenous. Certain work, however, argues that oil prices respond to factors that also affect stock prices (Barsky and Kilian 2002, 2004; Hamilton 2005; Kilian 2008b). Thus, researchers must decompose aggregate oil price shocks into the structural factors that reflect the endogenous character of such shocks.

Thus, this paper investigates how the explicit structural shocks characterizing the endogenous character of oil-price changes affect stock prices across a sample of eight countries - Australia, Canada, France, Germany, Italy, Japan, the United Kingdom, and the United States. For each country, the analysis proceeds in two steps. First, modifying the 
procedure of Kilian (2008a), we employ a vector error-correction or a vector autoregressive model to decompose oil-price changes into three components: oil-supply shocks, global aggregate-demand shocks, and global oil-demand shocks. The last component relates to specific idiosyncratic features of the oil market, such as changes in the precautionary demand concerning the uncertainty about the availability of future oil supplies. Second, recovering the oil-supply shocks, global aggregate-demand shocks, and global oil-demand shocks from the first analysis, we then employ a vector autoregressive model to determine the effects of these structural shocks on the stock market returns in our sample of eight countries. For completeness and comparison to Kilian and Park (2007), we also estimate vector autoregressive models where the changes in the level variables from the oil market replace the oil-market shocks. The rest of the paper is organized as follows. Section 2 presents the empirical methodology. Section 3 reports and discusses the empirical results. Finally Section 4 concludes and provides implications of the results as well as suggestions for further research.

\section{Methodology}

The proposed methodology considers oil prices as potentially endogenous in an economic framework. This will enable researchers as well as policy makers to identify explicitly the exact effects of oil prices changes on certain substantial macroeconomic variables and/or asset prices, such as stock prices. The methodology uses the vector error-correction (VEC) or vector autoregressive (VAR) model as appropriate, where we decompose the unpredictable changes in real oil prices into mutually orthogonal components. Such decompositions carry a significant economic interpretation and reveal certain implications for both researchers and policy makers. In particular, the VEC or VAR model contains three variables, global oil production $(O Y)$, global real economic activity $(Y Y)$, and real oil prices (oil prices deflated by the CPI index), $(R O P)$. In the VEC model, we also include the error-correction term that 
emerges because of a long-term cointegrated relationship between these three variables. The VEC form is given as follows:

$$
\Delta X_{t}=\alpha+\sum_{i=1}^{p} \beta_{i} \Delta X_{t-i}+\delta E C_{t-1}+e_{t}
$$

where $X$ is a $3 \times 1$ vector of the variables entering the VER model -- global oil production, global real economic activity, and real oil prices, $\Delta$ is the first-difference operator, $E C$ is the error-correction term that comes from the cointegrating relationship between the three variables, and $e$ is a $3 \times 1$ vector of residuals from the VEC model. Setting the coefficient of the error-correction term to zero produces the VAR model as follows:

$$
\Delta X_{t}=\alpha+\sum_{i=1}^{p} \beta_{i} \Delta X_{t-i}+e_{t}
$$

Next, we define $\varepsilon$ as the vector of serially and mutually uncorrelated structural innovations obeying a specific structural pattern, such as:

$$
\left[\begin{array}{c}
e^{O Y} \\
e^{Y Y} \\
e^{R O P}
\end{array}\right]=\left[\begin{array}{ccc}
1 & 0 & 0 \\
a_{21} & 1 & 0 \\
a_{31} & a_{32} & 1
\end{array}\right]\left[\begin{array}{c}
\varepsilon^{\text {oil-supply shock }} \\
\varepsilon^{\text {global-demand shock }} \\
\varepsilon^{\text {idiosyncratic demand shock }}
\end{array}\right] .
$$

The assumptions that characterize the behavior of the error structure come from Kilian (2008a) and include the following. First, we assume that global oil production shocks (a proxy for oil-supply shocks, OSS) do not respond to the other two shocks - global-demand and idiosyncratic shocks. Second, we assume that global real-activity shocks (a proxy for global aggregate-demand shocks, GDS) respond to oil-supply shocks, suggesting a sluggish response of global real economic activity to changes in oil prices. Finally, we assume that real oil-price shocks (a proxy for idiosyncratic demand shocks, IDS) respond to both oilsupply and global aggregate-demand shocks, reflecting the importance of fluctuations in precautionary demand for oil driven by fears concerning the availability of future oil supplies as well as the importance of certain oil sector-specific policies, such as inventory policies. 
The exogeneity of the oil-supply shock rests on the grounds that oil production reacts slowly to changes in demand shocks, a fact mainly attributable to the high costs of oil-production adjustment and/or to the high uncertainty in the oil market.

Kilian and Park (2007) provide the basic framework for our analysis with some notable adjustments to their original methodology. To wit, they estimate a structural VAR model for the four variables as follows: the percentage change in world crude oil production, global real economic activity, the real oil price, and return on U.S. stocks. As we show below, the percentage change in world crude oil production and the return on U.S. stocks are stationary variables (i.e., I(0) variables) whereas global real economic activity and the real price of oil are non-stationary variables (i.e., I(1) variables). Thus, we argue that Kilian and Park (2007) estimate a structural VAR model that incorporates variables with inconsistent time-series properties.

Thus, we modify Kilian's (2008a) procedure for recovering oil market shocks by estimating a three variable structural VEC or VAR model, using global oil production (and not its percentage change), global real economic activity, and the real price of oil. As such, our three variables prove consistent in a time-series sense, since they all are I(1). Next, we recover the structural shocks from the three-variable structural VEC or VAR to combine with the stock market return in a four-variables structural VEC or VAR model. Note that the stock market return is $I(0)$ as are the three structural shocks. That is, we achieve consistency in the time-series properties of the variables in our four-variable structural VEC or VAR.

For comparison purposes, we also estimate a four-variable structural VEC or VAR that comes closer to the specification of Kilian and Park (2007). Here, we use global oil production (and not its percentage change), global real economic activity, the real price of oil, and the stock market price (and not its rate of return). Thus, each of the four variables is I(1), 
once again achieving consistency in the time-series properties of the variables included in the four-variable VEC or VAR.

\section{Empirical Analysis}

\subsection{Data}

We collect monthly data on goods prices $(P)$ proxied by the consumer price index $(\mathrm{CPI})$, global real economic activity proxied by a global index of dry cargo single voyage freight rates, ${ }^{1}$ the international oil price $(O P)$ proxied by the US price per barrel of crude oil, oil production proxied by the US price per barrel of crude oil, and stock market price $(S P)$ in each country. Kilian (2008a) argues for the validity of the dry-cargo single-voyage freight rates as a proxy for global economic activity on the grounds that these rates rise and fall with rises and falls in global demand. That is, rising global demand leads to rising trade and rising demand for shipping services. Consequently, rising global demand should associate with rising freight rates. The proxy for world demand sidesteps a sticky issue with individual country data. To wit, researchers typically approximate global demand with some weighted average of the larger individual country demands. The index of freight weights potentially captures changes in total world demand, including the smaller countries omitted by those indexes that use aggregates of individual country data.

The monthly sample for the eight countries -- Australia, Canada, France, Germany, Italy, Japan, the United Kingdom, and the United States - spans 1981 to 2007 inclusive for a total of 324 observations for each country. Data on consumer price indices and oil prices come from the International Financial Statistics (IFS) database, while stock market prices come from Datastream. ${ }^{2}$

\footnotetext{
1 Kilian provides his proxy for global real economic activity on his website at http://wwwpersonal.umich.edu/ lkilian/paperlinks.html.

${ }^{2}$ Stock market prices reflect the following markets: Australia by the Australian General Market Index, Canada by the C.L. Toronto Index, Germany by the DAX index, France by the CAC Industrial Index, Italy by the Milan
} 
For our empirical analysis, we deflate oil prices as well as stock prices by goods prices (i.e., the respective CPI). Next, we compute stock returns as differences in the natural logarithm of real stock market prices. We employ RATS software (version 7.0) in the empirical analysis.

\subsection{Unit Root Tests}

We test for unit roots in the natural logarithms of our variables for each country. We test the null hypothesis of non-stationary variables versus the alternative hypothesis of stationary variables using the Augmented Dickey-Fuller (ADF) statistic (Dickey and Fuller, 1981). We employ the Akaike information criteria (AIC) to select the lag length from the ADF test. Table 1 reports the results with and without a trend. With one exception, we cannot reject the null hypothesis that all variables contain a unit root at the 5-percent significant level, suggesting that the natural logarithm of all variables in our study are I(1). For the exception, global oil production, we cannot reject the null hypothesis of a unit root at the 1-percent level.

\subsection{Cointegration Tests}

We employ cointegration tests, based on the methodology of Johansen and Juselius (1990), for the variables that characterize the global oil market -- global oil production, global real economic activity, and real oil prices. Table 2 reports the tests for cointegration. As a pre-test, we estimate VAR models with varying lag lengths and perform F-tests to select the appropriate lag length. In all cases, we choose seven lags. ${ }^{3}$ Both the eigenvalue and the trace test statistics recommend that a long-run relationship does not exist among the three jointly determined variables in either case. ${ }^{4}$

IB 30 index, Japan by the Nikkei Stock Index, the United Kingdom by the Financial Times 30 index, and the United States by the NYSE index.

${ }^{3}$ Since two variables are identical across the countries and the third variable is the real oil price in each country, we do not anticipate that the results will differ dramatically across countries. Thus, finding the same lag length in each country does not raise concerns.

${ }^{4}$ Thus, since we do not employ cointegration, our finding that the log-level of oil supply does not contain a unit root does not create any problems. 
Thus, we proceed to estimate VAR models for all eight countries. Since two of the variables - global oil production and global real economic activity - do not change across the eight different specifications, we do not expect dramatic differences in results. That is, only the real oil price differs across countries due to different CPI deflators used to generate the real oil price in each country.

\subsection{Variance Decomposition Tests}

Table 3 reports the variance decompositions results for the effects of various oil-price shocks involved in the VAR model only on the real price of oil $(R O P)$ to conserve space. All VAR models include seven lags. The numbers reported indicate the percentage of the forecast error in each variable that we can attribute to each of the structural innovations at different horizons (from 1 month to 60 months). We report the percentages for selected forecast horizons (1, 6, 12, 36, 60 months).

The decomposition results show that even in the long-run (i.e., the 60-month forecast horizon), global aggregate-demand shocks contribute a relatively small share to the variation in real oil prices. In the short run (i.e., 1-month forecast horizon), oil-supply and globaldemand shocks produce slightly less than 3-percent of the variation in the real price of oil across all eight countries in our sample. Extending the focus to the long-run (i.e., 60-month forecast horizon, the oil-supply and global-demand shocks only generate between 7- and 8percent of the variation of real oil price variation. In addition, the speed with which the variance decomposition reaches its long-run equilibrium occurs rather quickly, falling within the range of 22 to 32 months for all countries.

In sum, while the variance decompositions show that oil-supply and global-demand shocks frequently exhibit significant effects on the real oil-price shock, these effects proves small in magnitude. Moreover, the long-run equilibrium decomposition occurs within a short time horizon of between 22 to 32 months. 


\subsection{Structural Oil Price Shocks and Stock Returns}

This section investigates how the structural oil price innovations relate to asset prices, such as stock returns $(r)$, where stock-market return equals the difference in natural logarithms of the stock-market index. That is, we recover the structural shocks from the three-variable VAR model and combine them with the stock-market return to produce a 4-varaible model.

We, once again, test the null hypothesis of non-stationary variables versus the alternative hypothesis of stationary variables using the Augmented Dickey-Fuller (ADF) statistic (Dickey and Fuller, 1981). Table 1 reports the unit-root tests for the three structural shocks and the stock-market returns, indicating that we can reject the null hypothesis of a unit root in each case. As before, the AIC statistic determines the lag length on the ADF test. That is, these four variables prove stationary. Thus, we employ a four-variable VAR model, involving the stock-market returns and the three structural shocks. We do not need to consider cointegration, in this case. In addition, each VAR model incorporates seven lags.

Table 4 reports the variance decompositions results for the effects of each of the three structural oil shocks plus the stock-market returns shocks only on stock-market returns (to conserve space). The numbers reported, again, indicate the percentage of the forecast error in each variable that we can attribute to each of the innovations at different horizons (from 1 month to 60 months). We report the percentages for selected forecast horizons $(1,6,12,36$, 60 months). Moreover, we also observe, once again, that the decompositions reach a long-run equilibrium rapidly, ranging from 15 to 22 months.

The decomposition results uncover a pattern for the three structural oil shocks. All three oil-market shocks contribute little to the variation in the stock market returns in each country. Italy provides the case where oil-market shocks generate the largest effect on the variation of the stock market return - less than 17-percent. For the remaining seven countries, the total effect of the oil-market shocks on explaining the variation of stock-market returns 
range from a low of 7.78 percent to a high of 12.12 percent. Although oil-market shocks frequently exhibit significant effects on the variation in the stock-market return, these effects prove, once again, small in magnitude. The results suggest that oil-market shocks exert a minor influence on stock market returns.

For comparison purposes, we also performed tests on a 4-variable VAR system global oil production, global real economic activity, the real oil price, and the real stock market price. These VAR models capture the spirit of Kilian and Park (2007), but ensure that the variables employed exhibit the same time series properties (i.e., each variable proves integrated of order one). ${ }^{5}$ As noted in the text, Kilian and Park (2007) use the percentage change in global oil production and the real stock return, both of which prove stationary in our analysis, along with global real economic activity and the real oil price. In other words, Kilian and Park (2007) appear to use two I(1) and two I(0) variables in their VAR system. The results of our 4-variabeles VAR model produces findings consistent to those reported in the text. Results of these alternative 4-variabel VAR models are available on request.

Kilian and Park (2007) report results form the United States with, as just described, a slightly different specification. Our findings do not differ dramatically from theirs. They find a slightly smaller effect of oil market shocks on the stock market return in the short run and a significantly higher effect in the longer run, where the three shocks explain around 11 percent at 12 months and just over 22 percent at infinity. We explain just over 12 percent after 12 months, and this does not change through 60 months. In addition, they report results that continue to increase the percentage of the stock-market return explained over time, although not by much. Our findings reach long-run equilibrium after 22 months.

Finally, we consider the potential temporal causality of our three oil-market shocks on the stock market returns in the eight countries in our sample. Table 5 reports the results of

\footnotetext{
${ }^{5}$ We impose the assumption that the log level of oil supply does contain a unit root.
} 
Granger temporal causality tests. We find a consistent pattern for four countries - Germany, Italy, the United Kingdom, and the United States. To wit, the real oil price shock temporally causes the stock market return at the 5-percent level or better. In Australia's case, only oil supply shocks temporally cause the stock market return, whereas in France's case, only global aggregate demand shocks temporarily lead the stock-market return. For Canada and Japan, we uncover no causality effects. Finally, we find no temporal causality of the oilmarket shocks on the stock-market return.

\section{Conclusions, Implications, and Suggestions for Further Research}

Our paper provides the first multi-country examination of the effects of oil-market shocks on stock markets. This study includes a sample of eight countries, - Australia, Canada, France, Germany, Italy, Japan, the United Kingdom, and the United States. Using the methodology of Kilian (2008a), we compute three different structural shocks for the oil market that captures oil supply shocks, global aggregate-demand shocks, and idiosyncratic demand shocks. Recovering the three structural shocks from the first-stage calculation, we combine those shocks with the stock-market returns to consider how the oil market structural shocks affect the evolution of the stock market returns.

The results show that different oil-market structural shocks play a significant role in explaining the adjustments in stock-market returns. But, the magnitude of such effects proves small. More specifically, oil-supply shocks, aggregate global-demand shocks, and oil-market idiosyncratic demand shocks all contribute significantly to explaining stock-market returns in most countries from the variance decompositions. The oil-supply and global aggregatedemand shocks do not significantly explain the stock return in Australia, whereas the idiosyncratic demand shocks affect the stock return in Canada at a weaker level of significance. Further, the Granger temporal causality tests suggest a strong role for 
idiosyncratic demand shocks leading the stock market returns, whereas the oil-supply and global aggregate-demand shocks do not as a rule temporally lead the stock-market return.

Future research efforts could also investigate the effect of such structural oil-market shocks on real stock returns across manufacturing industries for a panel of countries. The empirical findings will prove extremely useful to investors who need to understand the exact effect of international oil price changes on certain stocks across industries. 


\section{References}

Barsky, R. B. and Kilian, L. (2004) "Oil and the Macroeconomy since the 1970s., Journal of Economic Perspectives 18, 115-134.

Barsky, R. B. and Kilian, L. (2002) "Do we Really Know that Oil Caused the Great Stagflation? A Monetary Alternative.” NBER Macroeconomics Annual 2001, 137183.

Bittlingmayer, G. (2005) “Oil and Stocks: Is it War Risk?” Working Paper Series, University of Kansas.

Chen, N. F., Roll, R. and Ross, S. A. (1986) "Economic Forces and the Stock Market." Journal of Business 59, 383-403.

Davis, J. S. and Haltiwanger, J. (2001) "Sectoral Job Creation and Destruction Responses to Oil Price Changes.” Journal of Monetary Economics 48, 465-512.

Dickey, D.A. and Fuller, W.A. (1981) "Likelihood Ratio Statistics for Autoregressive Time Series With a Unit Root.” Econometrica 49, 1057-1072.

Driesprong, G., Jacobsen, B. and Benjiman, M. (2003) "Striking Oil: Another Puzzle?" Working Paper, Erasmus University Rotterdam.

Faff, R. W. and Brailsford, T. J. (2000) “A Test of a Two-Factor 'Market and Oil' Pricing Model." Pacific Accounting Review 12, 61-77.

Gisser, M. and Goodwin, T. H. (1986) "Crude Oil and the Macroeconomy: Tests of Some Popular Notions: Note.” Journal of Money, Credit and Banking 18, 95-103.

Gogineni, S. (2007) "The Stock Market Reaction to Oil Price Changes." Working Paper, University of Oklahoma.

Hamilton, J. D. (2005) “Oil and the Macroeconomy.” in S. Durlauf and L. Blume (eds.), The New Palgrave Dictionary of Economics, $2^{\text {nd }}$ Edition, London: Macmillan.

Hamilton, J. D. (2003) “What is an Oil Shock?” Journal of Econometrics 113, 363-398. 
Hamilton, J. D. (1983) "Oil and the Macroeconomy since World War II." The Journal of Political Economy 9, 228-248.

Hamilton, J. D. and Herrera, M. A. (2002) "Oil Shocks and Aggregate Macroeconomic Behavior." Journal of Money, Credit and Banking 36, 265-286.

Hammoudeh, S. and Li, H. (2004) "Risk-Return Relationships in Oil-Sensitive Stock Markets.” Finance Letters 2, 10-15.

Hammoudeh, S. and Eleisa, E. (2004) "Dynamic Relationships among the GCC Stock Markets and the NYMEX Oil Prices.” Contemporary Economic Policies 22, 250-269.

Hong, H., Torous, W. and Valkanov, R. (2002) "Do Industries lead the Stock Market? Gradual Diffusion of Information and Cross-Asset Return Predictability.” Working Paper, Stanford University and UCLA.

Hooker, M. A. (2002) “Are Oil Shocks Inflationary? Asymmetric and Nonlinear Specifications versus Changes in Regime.” Journal of Money, Credit and Banking 34, $540-561$.

Hooker, M. A. (1996) "What Happened to the Oil-Price Macroeconomy Relationship?" Journal of Monetary Economics 38, 195-213.

Huang, R., Masulis, R. and Stoll, H. (1996) “Energy Shocks and Financial Markets.” Journal of Futures Markets 16, 1-17.

Im, K. S., Pesaran, M. H., and Shin Y. (1995) "Testing for Unit Roots in Heterogeneous Panels." Working Paper 9526, Department of Applied Economics, Cambridge University.

Jones, D. W., Lelby, P. N. and Paik, I. K. (2004) "Oil Price Shocks and the Macroeconomy: What Has Been Learned Since 1996?" Energy Journal 25, 1-32.

Jones, C. and Kaul, G. (1996) “Oil and the Stock Markets.” Journal of Finance 51, 463-491. 
Kaul, G. and Seyhun, N. (1990) "Relative Price Variability, Real Shocks, and the Stock Market." The Journal of Finance 45, 479-496.

Kilian, L. (2008a) "Not All Oil Price Shocks are Alike: Disentangling Demand and Supply Shocks in the Crude Oil Market." American Economic Review in press.

Kilian, L. (2008b) "Exogenous Oil Supply Shocks: How Big Are They and How Much do they Matter for the US Economy?" Review of Economics and Statistics 90. 216-240

Kilian, L. and Park, C. (2007) "The Impact of Oil Price Shocks on the U.S. Stock Market." CPER Discussion Paper 6166.

Lee, K. and Ni, S. (2002) "On the Dynamic Effects of Oil Shocks: A Study Using Industry Level Data." Journal of Monetary Economics 49, 823-852.

Mork, A. K. (1989) "Oil and the Macroeconomy when Prices Go Up and Down: An Extension of Hamilton's Results.” The Journal of Political Economy 97, 740-744.

Pedroni, P. (1999) "Critical Values for Cointegration Tests in Heterogeneous Panels with Multiple Regressors." Oxford Bulletin of Economics and Statistics 61, Special Issue, 653-670.

Pollet, J. (2002) "Predicting Asset Returns with Expected Oil Price Changes." Working Paper, Harvard University.

Sadorsky, P. (1999) “Oil Price Shocks and Stock Market Activity.” Energy Economics 2, 449-469.

Sawyer, K. R. and Nandha, M. (2006) “How Oil Moves Stock Prices.” Working Paper Series, University of Melbourne.

Wei, C. (2003) "Energy, the Stock Market, and the Putty-Clay Investment Model." American Economic Review 93, 311-323. 
Table 1: Unit-Root Tests

\begin{tabular}{cclll}
\hline Variables & Without Trend $\begin{array}{c}\text { With Trend } \\
\text { Levels }\end{array}$ & $\begin{array}{c}\text { Without Trend } \\
\text { First Differences }\end{array}$ \\
\hline WY & $-0.32(12)$ & $-4.13(12)^{* * *}$ & $-5.91(12)^{* * * *}$ & $-5.88(12)^{* * *}$ \\
$Y Y$ & $-1.01(12)$ & $-2.61(12)$ & $-3.85(12)^{* * *}$ & $-3.88(12)^{* *}$ \\
Australia & & & & \\
$R O P$ & $-1.97(11)$ & $-1.42(12)$ & $-5.17(12)^{* * * *}$ & $-5.59(12)^{* * *}$ \\
$r$ & $-5.89(12)^{* * *}$ & $-5.86(12)^{* * *}$ & & \\
$\varepsilon^{O S S}$ & $-5.35(11)^{* * *}$ & $-5.34(11)^{* * *}$ & & \\
$\varepsilon_{G D S}^{G D *}$ & $-3.72(12)^{* * *}$ & $-3.72(12)^{* *}$ & & \\
$\varepsilon^{I D S}$ & $-4.42(12)^{* * *}$ & $-4.88(12)^{* * *}$ & &
\end{tabular}

Canada

$\begin{array}{lll}R O P & -1.70(11) & -1.40(12) \\ r & -5.98(12)^{* * *} & -5.94(12)^{* * *} \\ \varepsilon^{O S S} & -5.36(11)^{* * *} & -5.35(11)^{* * *} \\ \varepsilon^{G D S} & -3.73(12)^{* * *} & -3.72(12)^{* *} \\ { }_{\varepsilon}^{I D S} & -4.51(12)^{* * *} & -4.88(12)^{* * *}\end{array}$

$-5.19(12)^{* * *}-5.58(12)^{* * *}$

France

$\begin{array}{lll}R O P & -1.55(11) & -1.43(12) \\ r & -4.85(9)^{* * *} & -4.86(9)^{* * *} \\ \varepsilon^{O S S} & -5.37(11)^{* * *} & -5.36(11)^{* * *} \\ \varepsilon^{G D S} & -3.73(12)^{* * *} & -3172(12)^{* *} \\ \varepsilon^{I D S} & -4.46(12)^{* * *} & -4.95(12)^{* * *}\end{array}$

Germany

$\begin{array}{lll}R O P & -1.66(114) & -1.47(12) \\ r & -5.08(9)^{* * *} & -5.15(9)^{* * *} \\ { }_{\varepsilon}^{O S S} & -5.37(11)^{* * *} & -5.36(11)^{* * *} \\ \varepsilon^{G D S} & -3.72(12)^{* * *} & -3.71(12)^{* * *} \\ { }_{\varepsilon}^{I D S} & -4.53(12)^{* * *} & -4.93(12)^{* * *}\end{array}$

Italy

$\begin{array}{lll}R O P & -2.04(11) & -1.32(12) \\ r & -3.44(12)^{* *} & -3.49(12)^{* *} \\ \varepsilon^{O S S} & -5.36(11)^{* * *} & -5.36(11)^{* * *} \\ \varepsilon^{G D S} & -3.73(12)^{* * *} & -3.72(12)^{* *} \\ { }_{\varepsilon}^{I D S} & -4.38(12)^{* * *} & -4.94(12)^{* * *}\end{array}$

$-5.21(12)^{* * *}-5.58(12)^{* * *}$

Japan

$\begin{array}{lll}R O P & -0.91(12) & -1.36(12) \\ r & -6.93(4)^{* * *} & -5.36(8)^{* * *} \\ { }_{\varepsilon}^{O S S} & -5.12(11)^{* * *} & -5.34(11)^{* * *} \\ \varepsilon^{G D S} & -3.73(12)^{* * *} & -3.72(12)^{* *} \\ { }_{\varepsilon}^{I D S} & -4.54(12)^{* * *} & -4.98(12)^{* * *}\end{array}$

$-5.11(12)^{* * *}-5.60(12)^{* * *}$

$-5.24(12)^{* * *}-5.59(12)^{* * *}$ 
Table 1: $\quad$ Unit-Root Tests (continued)

\begin{tabular}{|c|c|c|c|c|}
\hline \multirow[b]{2}{*}{ United Kingdom } & \multicolumn{2}{|c|}{$\begin{array}{c}\text { Without Trend With Trend } \\
\text { Levels }\end{array}$} & \multicolumn{2}{|c|}{$\begin{array}{c}\text { Without Trend With Trend } \\
\text { First Differences }\end{array}$} \\
\hline & & & & \\
\hline$R O P$ & $-1.71(11)$ & $-1.29(12)$ & $-5.18(12)^{* * *}$ & $-5.58(12) * * *$ \\
\hline$r$ & $-5.12(9) * * *$ & $-5.91(9) * * *$ & & \\
\hline$\varepsilon^{O S S}$ & $-5.58(11)^{* * *}$ & $-5.36(11)^{* * *}$ & & \\
\hline$\varepsilon^{G D S}$ & $-3.73(12) * * *$ & $-3.72(12)^{* *}$ & & \\
\hline$\varepsilon^{I D S}$ & $-4.47(12) * * *$ & $-4.96(12)^{* * *}$ & & \\
\hline \multicolumn{5}{|l|}{ United States } \\
\hline$R O P$ & $-1.80(11)$ & $-1.40(12)$ & $-5.22(12) * * *$ & $-5.55(12) * * *$ \\
\hline$r$ & $-3.88(4) * *$ & $-4.78(11)^{* * *}$ & & \\
\hline$\varepsilon^{O S S}$ & $-5.36(11)^{* * *}$ & $-5.34(11)^{* * *}$ & & \\
\hline$\varepsilon^{G D S}$ & $-3.72(12)^{* * *}$ & $-3.72(12)^{* *}$ & & \\
\hline$\varepsilon^{I D S}$ & $-4.53(12)^{* * *}$ & $-4.96(12)^{* * *}$ & & \\
\hline
\end{tabular}

Note: $\quad O Y$ is the log of global oil production, $Y Y$ is the $\log$ of real economic activity, $R O P$ is the log of real oil prices, $r$ is stock returns, $\varepsilon^{O S S}$ is the structural oil supply shock, $\varepsilon^{G D S}$ is the structural global demand shock, and $\varepsilon^{I D S}$ is the structural idiosyncratic demand shock. Figures in brackets denote the number of lags in the augmented term that ensures white-noise residuals. We determined the optimal lag length through the Akaike information Criterion (AIC) and the Schwarz-Bayes Information Criterion (SBIC), whose critical values equal the following values: 1 -percent $=-3.45,5$-percent $=-2.87,10$-percent $=-2.56$.

*** $\quad$ Significant at $1 \%$.

$* * \quad$ Significant at $5 \%$. 
Table 2: $\quad$ Cointegration Tests

\begin{tabular}{|c|c|c|c|c|c|}
\hline$r$ & n-r & $\mathbf{m} . \lambda$. & $95 \%$ & $\mathbf{T r}$ & $95 \%$ \\
\hline \multicolumn{6}{|c|}{ Australia (Lags $=7)$} \\
\hline $\mathrm{r}=0$ & $\mathrm{r}=1$ & 19.1125 & 25.8100 & 31.0784 & 35.0700 \\
\hline $\mathrm{r}<=1$ & $\mathrm{r}=2$ & 7.2184 & 11.4600 & 11.9609 & 20.1600 \\
\hline $\mathrm{r}<=2$ & $\mathrm{r}=3$ & 4.7425 & 9.1400 & 4.7425 & 9.1400 \\
\hline \multicolumn{6}{|c|}{$\overline{\text { Canada }(\text { Lags }=7)}$} \\
\hline $\mathrm{r}=0$ & $\mathrm{r}=1$ & 19.3595 & 25.8100 & 30.5154 & 35.0700 \\
\hline $\mathrm{r}<=1$ & $\mathrm{r}=2$ & 6.2921 & 11.4600 & 11.1560 & 20.1600 \\
\hline $\mathrm{r}<=2$ & $\mathrm{r}=3$ & 4.8639 & 9.1400 & 4.8639 & 9.1400 \\
\hline \multicolumn{6}{|c|}{$\overline{\text { France }(\text { Lags }=7)}$} \\
\hline $\mathrm{r}=0$ & $\mathrm{r}=1$ & 19.8392 & 25.8100 & 31.3614 & 35.0700 \\
\hline $\mathrm{r}<=1$ & $\mathrm{r}=2$ & 6.5962 & 11.4600 & 11.5222 & 20.1600 \\
\hline $\mathrm{r}<=2$ & $\mathrm{r}=3$ & 4.8260 & 9.1400 & 4.8260 & 9.1400 \\
\hline \multicolumn{6}{|c|}{ Germany $($ Lags $=7)$} \\
\hline $\mathrm{r}=0$ & $\mathrm{r}=1$ & 19.4305 & 25.8100 & 29.9744 & 35.0700 \\
\hline $\mathrm{r}<=1$ & $\mathrm{r}=2$ & 5.5501 & 11.4600 & 10.5439 & 20.1600 \\
\hline $\mathrm{r}<=2$ & $\mathrm{r}=3$ & 4.9938 & 9.1400 & 4.9938 & 9.1400 \\
\hline \multicolumn{6}{|l|}{ Italy $($ Lags $=7)$} \\
\hline $\mathrm{r}=0$ & $\mathrm{r}=1$ & 20.1190 & 25.8100 & 32.8336 & 35.0700 \\
\hline $\mathrm{r}<=1$ & $\mathrm{r}=2$ & 7.9983 & 11.4600 & 12.7146 & 20.1600 \\
\hline $\mathrm{r}<=2$ & $\mathrm{r}=3$ & 4.7163 & 9.1400 & 4.7164 & 9.1400 \\
\hline \multicolumn{6}{|l|}{ Japan $($ Lags $=7)$} \\
\hline $\mathrm{r}=0$ & $\mathrm{r}=1$ & 19.2739 & 25.8100 & 30.1623 & 35.0700 \\
\hline $\mathrm{r}<=1$ & $r=2$ & 5.3234 & 11.4600 & 10.8284 & 20.1600 \\
\hline $\mathrm{r}<=2$ & $\mathrm{r}=3$ & 5.3052 & 9.1400 & 5.3052 & 9.1400 \\
\hline \multicolumn{6}{|c|}{ United Kingdom $(\operatorname{Lags}=7)$} \\
\hline $\mathrm{r}=0$ & $\mathrm{r}=1$ & 18.7061 & 25.8100 & 30.0768 & 35.0700 \\
\hline $\mathrm{r}<=1$ & $\mathrm{r}=2$ & 6.4261 & 11.4600 & 11.3707 & 20.1600 \\
\hline $\mathrm{r}<=2$ & $\mathrm{r}=3$ & 4.9445 & 9.1400 & 4.9445 & 9.1400 \\
\hline \multicolumn{6}{|c|}{ United States $($ Lags $=7)$} \\
\hline $\mathrm{r}=0$ & $\mathrm{r}=1$ & 18.9051 & 25.8100 & 29.6546 & 35.0700 \\
\hline $\mathrm{r}<=1$ & $\mathrm{r}=2$ & 5.9236 & 11.4600 & 10.7495 & 20.1600 \\
\hline $\mathrm{r}<=2$ & $\mathrm{r}=3$ & 4.8258 & 9.1400 & 4.8258 & 9.1400 \\
\hline
\end{tabular}

Note: $\quad \mathrm{r}=$ number of cointegrating vectors, $\mathrm{n}-\mathrm{r}=$ number of common trends, $\mathrm{m} . \lambda .=$ maximum eigenvalue statistic, $\mathrm{Tr}=$ trace statistic. 
Table 3: $\quad$ Variance Decomposition Tests (Oil Shocks)

\begin{tabular}{|c|c|c|c|}
\hline \multicolumn{4}{|c|}{ Real Oil Price $(R O P)$} \\
\hline Months & $O Y$ & $\boldsymbol{Y} \boldsymbol{Y}$ & $\underline{R O P}$ \\
\hline \multicolumn{4}{|l|}{ Australia (27) } \\
\hline 1 & $\begin{array}{c}0.22 \\
(? . ? ?)\end{array}$ & $\begin{array}{c}2.55 \\
(? . ? ?)\end{array}$ & $\begin{array}{l}97.23 \\
(? . ? ?)\end{array}$ \\
\hline 6 & $\begin{array}{c}2.38 \\
(? . ? ?)\end{array}$ & $\begin{array}{c}4.20 \\
(? . ? ?)\end{array}$ & $\begin{array}{l}93.42 \\
(? . ? ?)\end{array}$ \\
\hline 12 & $\begin{array}{c}3.16 \\
(? . ? ?)\end{array}$ & $\begin{array}{c}4.43 \\
(? . ? ?)\end{array}$ & $\begin{array}{l}92.41 \\
(? . ? ?)\end{array}$ \\
\hline 36 & $\begin{array}{c}3.21 \\
(? . ? ?)\end{array}$ & $\begin{array}{c}4.43 \\
(? . ? ?)\end{array}$ & $\begin{array}{l}92.36 \\
(? . ? ?)\end{array}$ \\
\hline 60 & $\begin{array}{c}3.21 \\
(? . ? ?)\end{array}$ & $\begin{array}{c}4.43 \\
(? . ? ?)\end{array}$ & $\begin{array}{l}92.36 \\
(? . ? ?)\end{array}$ \\
\hline \multicolumn{4}{|l|}{ Canada (23) } \\
\hline 1 & $\begin{array}{c}0.21 \\
(? . ? ?)\end{array}$ & $\begin{array}{c}2.71 \\
(? . ? ?)\end{array}$ & $\begin{array}{l}97.09 \\
(? . ? ?)\end{array}$ \\
\hline 6 & $\begin{array}{c}2.30 \\
(? . ? ?)\end{array}$ & $\begin{array}{c}4.41 \\
(? . ? ?)\end{array}$ & $\begin{array}{l}93.30 \\
(? . ? ?)\end{array}$ \\
\hline 12 & $\begin{array}{c}3.08 \\
(? . ? ?)\end{array}$ & $\begin{array}{c}4.63 \\
(? . ? ?)\end{array}$ & $\begin{array}{l}92.29 \\
(? . ? ?)\end{array}$ \\
\hline 36 & $\begin{array}{c}3.13 \\
(? . ? ?)\end{array}$ & $\begin{array}{c}4.63 \\
(? . ? ?)\end{array}$ & $\begin{array}{l}92.23 \\
(? . ? ?)\end{array}$ \\
\hline 60 & $\begin{array}{c}3.13 \\
(? . ? ?)\end{array}$ & $\begin{array}{c}4.63 \\
(? . ? ?)\end{array}$ & $\begin{array}{l}92.23 \\
(? . ? ?)\end{array}$ \\
\hline \multicolumn{4}{|l|}{ France (22) } \\
\hline 1 & $\begin{array}{c}0.17 \\
(? . ? ?)\end{array}$ & $\begin{array}{c}2.61 \\
(? . ? ?)\end{array}$ & $\begin{array}{l}97.23 \\
(? . ? ?)\end{array}$ \\
\hline 6 & $\begin{array}{c}2.23 \\
(? . ? ?)\end{array}$ & $\begin{array}{c}4.27 \\
(? . ? ?)\end{array}$ & $\begin{array}{l}93.51 \\
(? . ? ?)\end{array}$ \\
\hline 12 & $\begin{array}{c}2.99 \\
(? . ? ?)\end{array}$ & $\begin{array}{c}4.51 \\
(? . ? ?)\end{array}$ & $\begin{array}{l}92.50 \\
(? . ? ?)\end{array}$ \\
\hline 36 & $\begin{array}{c}3.03 \\
(? . ? ?)\end{array}$ & $\begin{array}{c}4.51 \\
(? . ? ?)\end{array}$ & $\begin{array}{l}92.45 \\
(? . ? ?)\end{array}$ \\
\hline 60 & $\begin{array}{c}3.03 \\
(? . ? ?)\end{array}$ & $\begin{array}{c}4.51 \\
(? . ? ?)\end{array}$ & $\begin{array}{l}92.45 \\
(? . ? ?)\end{array}$ \\
\hline \multicolumn{4}{|l|}{ Germany (28) } \\
\hline 1 & $\begin{array}{c}0.18 \\
(? . ? ?)\end{array}$ & $\begin{array}{c}2.75 \\
(? . ? ?)\end{array}$ & $\begin{array}{l}97.23 \\
(? . ? ?)\end{array}$ \\
\hline 6 & $\begin{array}{c}2.52 \\
(? . ? ?)\end{array}$ & $\begin{array}{c}4.52 \\
(? . ? ?)\end{array}$ & $\begin{array}{l}93.16 \\
(? . ? ?)\end{array}$ \\
\hline 12 & $\begin{array}{c}3.14 \\
(? . ? ?)\end{array}$ & $\begin{array}{c}4.72 \\
(? . ? ?)\end{array}$ & $\begin{array}{l}92.13 \\
(? . ? ?)\end{array}$ \\
\hline 36 & $\begin{array}{c}3.19 \\
(? . ? ?)\end{array}$ & $\begin{array}{c}4.23 \\
(? . ? ?)\end{array}$ & $\begin{array}{l}92.08 \\
(? . ? ?)\end{array}$ \\
\hline 60 & $\begin{array}{c}3.19 \\
(? . ? ?)\end{array}$ & $\begin{array}{c}4.23 \\
(? . ? ?)\end{array}$ & $\begin{array}{l}92.08 \\
(? . ? ?)\end{array}$ \\
\hline
\end{tabular}


Table 3: $\quad$ Variance Decomposition Tests (Oil Shocks) (continued)

\begin{tabular}{|c|c|c|c|}
\hline \multicolumn{4}{|c|}{ Real Oil Price $(R O P)$} \\
\hline Months & $O Y$ & $Y Y$ & $\underline{R O P}$ \\
\hline \multicolumn{4}{|l|}{ Italy (28) } \\
\hline 1 & $\begin{array}{c}0.21 \\
(? . ? ?)\end{array}$ & $\begin{array}{c}2.60 \\
(? . ? ?)\end{array}$ & $\begin{array}{l}97.20 \\
(? . ? ?)\end{array}$ \\
\hline 6 & $\begin{array}{c}2.41 \\
(? . ? ?)\end{array}$ & $\begin{array}{c}4.14 \\
(? . ? ?)\end{array}$ & $\begin{array}{l}93.34 \\
(? . ? ?)\end{array}$ \\
\hline 12 & $\begin{array}{c}3.17 \\
(? . ? ?)\end{array}$ & $\begin{array}{c}4.48 \\
(? . ? ?)\end{array}$ & $\begin{array}{l}92.35 \\
(? . ? ?)\end{array}$ \\
\hline 36 & $\begin{array}{c}3.21 \\
(? . ? ?)\end{array}$ & $\begin{array}{c}4.48 \\
(? . ? ?)\end{array}$ & $\begin{array}{l}92.31 \\
(? . ? ?)\end{array}$ \\
\hline 60 & $\begin{array}{c}3.21 \\
(? . ? ?)\end{array}$ & $\begin{array}{c}4.48 \\
(? . ? ?)\end{array}$ & $\begin{array}{l}92.31 \\
(? . ? ?)\end{array}$ \\
\hline \multicolumn{4}{|l|}{ Japan (22) } \\
\hline 1 & $\begin{array}{c}0.18 \\
(? . ? ?)\end{array}$ & $\begin{array}{c}2.61 \\
(? . ? ?)\end{array}$ & $\begin{array}{l}92.21 \\
(? . ? ?)\end{array}$ \\
\hline 6 & $\begin{array}{c}2.19 \\
(? . ? ?)\end{array}$ & $\begin{array}{c}4.19 \\
(? . ? ?)\end{array}$ & $\begin{array}{l}93.62 \\
(? . ? ?)\end{array}$ \\
\hline 12 & $\begin{array}{c}2.93 \\
(? . ? ?)\end{array}$ & $\begin{array}{c}4.42 \\
(? . ? ?)\end{array}$ & $\begin{array}{l}92.65 \\
(? . ? ?)\end{array}$ \\
\hline 36 & $\begin{array}{c}2.98 \\
(? . ? ?)\end{array}$ & $\begin{array}{l}4.43 \\
(? . ? ?)\end{array}$ & $\begin{array}{l}92.60 \\
(? . ? ?)\end{array}$ \\
\hline 60 & $\begin{array}{c}2.98 \\
(? ? ?)\end{array}$ & $\begin{array}{c}4.43 \\
(? . ? ?)\end{array}$ & $\begin{array}{l}92.60 \\
(? . ? ?)\end{array}$ \\
\hline \multicolumn{4}{|c|}{ United Kingdom (32) } \\
\hline 1 & $\begin{array}{c}0.13 \\
(? . ? ?)\end{array}$ & $\begin{array}{c}2.66 \\
(? . ? ?)\end{array}$ & $\begin{array}{l}97.21 \\
(? . ? ?)\end{array}$ \\
\hline 6 & $\begin{array}{c}2.18 \\
(? . ? ?)\end{array}$ & $\begin{array}{c}4.53 \\
(? . ? ?)\end{array}$ & $\begin{array}{l}93.49 \\
(? . ? ?)\end{array}$ \\
\hline 12 & $\begin{array}{c}3.04 \\
(? . ? ?)\end{array}$ & $\begin{array}{c}4.59 \\
(? . ? ?)\end{array}$ & $\begin{array}{l}92.37 \\
(? . ? ?)\end{array}$ \\
\hline 36 & $\begin{array}{c}3.08 \\
(? . ? ?)\end{array}$ & $\begin{array}{c}4.60 \\
(? . ? ?)\end{array}$ & $\begin{array}{l}92.32 \\
(? . ? ?)\end{array}$ \\
\hline 60 & $\begin{array}{c}3.08 \\
(? . ? ?)\end{array}$ & $\begin{array}{c}4.60 \\
(? . ? ?)\end{array}$ & $\begin{array}{l}92.32 \\
(? . ? ?)\end{array}$ \\
\hline \multicolumn{4}{|l|}{ United States (27) } \\
\hline 1 & $\begin{array}{c}0.21 \\
(? . ? ?)\end{array}$ & $\begin{array}{c}2.65 \\
(? . ? ?)\end{array}$ & $\begin{array}{l}97.14 \\
(? . ? ?)\end{array}$ \\
\hline 6 & $\begin{array}{c}2.32 \\
(? . ? ?)\end{array}$ & $\begin{array}{c}4.32 \\
(? . ? ?)\end{array}$ & $\begin{array}{l}93.36 \\
(? . ? ?)\end{array}$ \\
\hline 12 & $\begin{array}{c}3.14 \\
(? . ? ?)\end{array}$ & $\begin{array}{c}4.55 \\
(? . ? ?)\end{array}$ & $\begin{array}{l}92.31 \\
(? . ? ?)\end{array}$ \\
\hline 36 & $\begin{array}{c}3.19 \\
(? ? ?)\end{array}$ & $\begin{array}{c}4.56 \\
(? . ? ?)\end{array}$ & $\begin{array}{l}92.26 \\
(? . ? ?)\end{array}$ \\
\hline 60 & $\begin{array}{c}3.19 \\
(? . ? ?)\end{array}$ & $\begin{array}{c}4.56 \\
(? . ? ?)\end{array}$ & $\begin{array}{l}92.26 \\
(? . ? ?)\end{array}$ \\
\hline
\end{tabular}




\section{Table 3: $\quad$ Variance Decomposition Tests (Oil Shocks) (continued)}

Notes: Standard errors, estimated through Monte Carlo techniques and 1000 replications, appear in parentheses under percentage of variances explained. The numbers in parentheses after the country name represent the number of periods until the variance decomposition reaches a constant, unchanging value for all future periods. 
Table 4: $\quad$ Variance Decomposition Tests (Real Stock Return)

\begin{tabular}{|c|c|c|c|c|}
\hline \multirow{2}{*}{ Months } & \multicolumn{4}{|c|}{ Stocks Returns ( $r$ ) } \\
\hline & $\varepsilon^{O S S}$ & $\varepsilon^{G D S}$ & $\varepsilon^{I D S}$ & $r$ \\
\hline \multicolumn{5}{|l|}{ Australia (19) } \\
\hline \multirow[t]{2}{*}{1} & 1.16 & 0.02 & 0.39 & 98.44 \\
\hline & (?.??) & (?.??) & (?.??) & (?.??) \\
\hline \multirow[t]{2}{*}{6} & 3.17 & 2.69 & 3.20 & 90.94 \\
\hline & (?.??) & (?.??) & (?.??) & (?.??) \\
\hline \multirow[t]{2}{*}{12} & 4.29 & 2.95 & 3.68 & 89.10 \\
\hline & $(? . ? ?)$ & $(? . ? ?)$ & $(? . ? ?)$ & (?.??) \\
\hline \multirow[t]{2}{*}{36} & 4.31 & 2.97 & 3.68 & 89.05 \\
\hline & $(? . ? ?)$ & (?.??) & $(? . ? ?)$ & $(? . ? ?)$ \\
\hline \multirow[t]{2}{*}{60} & 4.31 & 2.97 & 3.68 & 89.05 \\
\hline & $(? . ? ?)$ & $(? . ? ?)$ & (?.??) & $(? . ? ?)$ \\
\hline \multicolumn{5}{|l|}{ Canada (20) } \\
\hline \multirow[t]{2}{*}{1} & 1.45 & 0.72 & 0.61 & 97.22 \\
\hline & $(? . ? ?)$ & $(? . ? ?)$ & $(? . ? ?)$ & $(? . ? ?)$ \\
\hline \multirow[t]{2}{*}{6} & 2.06 & 1.87 & 1.81 & 91.97 \\
\hline & $(? . ? ?)$ & $(? . ? ?)$ & $(? . ? ?)$ & $(? . ? ?)$ \\
\hline \multirow[t]{2}{*}{12} & 3.23 & 2.01 & 2.53 & 92.24 \\
\hline & (?.??) & (?.??) & $(? . ? ?)$ & $(? . ? ?)$ \\
\hline \multirow[t]{2}{*}{36} & 3.24 & 2.01 & 2.53 & 92.22 \\
\hline & $(? . ? ?)$ & $(? . ? ?)$ & $(? . ? ?)$ & (?.??) \\
\hline \multirow[t]{2}{*}{60} & 3.24 & 2.01 & 2.53 & 92.22 \\
\hline & $(? . ? ?)$ & $(? . ? ?)$ & $(? . ? ?)$ & (?.??) \\
\hline \multicolumn{5}{|l|}{ France (15) } \\
\hline \multirow[t]{2}{*}{1} & 0.77 & 0.67 & 0.45 & 98.12 \\
\hline & (?.??) & (?.??) & (?.??) & (?.??) \\
\hline \multirow[t]{2}{*}{6} & 2.50 & 3.39 & 4.34 & 89.77 \\
\hline & $(? . ? ?)$ & $(? . ? ?)$ & $(? . ? ?)$ & $(? . ? ?)$ \\
\hline \multirow[t]{2}{*}{12} & 2.71 & 4.60 & 4.43 & 88.26 \\
\hline & (?.??) & (?.??) & (?.??) & (?.??) \\
\hline \multirow[t]{2}{*}{36} & 2.72 & 4.60 & 4.43 & 88.25 \\
\hline & $(? . ? ?)$ & $(? . ? ?)$ & $(? . ? ?)$ & $(? . ? ?)$ \\
\hline \multirow[t]{2}{*}{60} & 2.72 & 4.60 & 4.43 & 88.25 \\
\hline & $(? . ? ?)$ & $(? . ? ?)$ & (?.??) & (?.??) \\
\hline \multicolumn{5}{|l|}{ Germany (21) } \\
\hline \multirow[t]{2}{*}{1} & 0.38 & 0.33 & 0.09 & 99.21 \\
\hline & $(? . ? ?)$ & $(? . ? ?)$ & $(? . ? ?)$ & $(? . ? ?)$ \\
\hline \multirow[t]{2}{*}{6} & 1.08 & 2.02 & 5.50 & 91.40 \\
\hline & $(? . ? ?)$ & $(? . ? ?)$ & $(? . ? ?)$ & $(? . ? ?)$ \\
\hline \multirow[t]{2}{*}{12} & 2.07 & 2.23 & 5.92 & 89.79 \\
\hline & $(? . ? ?)$ & $(? . ? ?)$ & $(? . ? ?)$ & (?.??) \\
\hline 36 & 2.09 & 2.23 & 5.92 & 89.77 \\
\hline & $(? . ? ?)$ & $(? . ? ?)$ & $(? . ? ?)$ & $(? . ? ?)$ \\
\hline 60 & 2.09 & 2.23 & 5.92 & 89.77 \\
\hline & (?.??) & (?.??) & (?.??) & (?.??) \\
\hline
\end{tabular}


Table 4: $\quad$ Variance Decomposition Tests (Real Stock Return) (continued)

\begin{tabular}{|c|c|c|c|c|}
\hline \multirow{2}{*}{ Months } & \multicolumn{4}{|c|}{ Stocks Returns (r) } \\
\hline & $\varepsilon^{\text {OSS }}$ & $\varepsilon^{G D S}$ & $\varepsilon^{I D S}$ & $\boldsymbol{r}$ \\
\hline \multicolumn{5}{|l|}{ Italy (19) } \\
\hline 1 & $\begin{array}{r}0.22 \\
(? . ? ?)\end{array}$ & $\begin{array}{c}1.38 \\
(? . ? ?)\end{array}$ & $\begin{array}{c}0.57 \\
(? . ? ?)\end{array}$ & $\begin{array}{l}98.04 \\
(? . ? ?)\end{array}$ \\
\hline 6 & $\begin{array}{r}3.24 \\
(? . ? ?)\end{array}$ & $\begin{array}{c}1.96 \\
(? . ? ?)\end{array}$ & $\begin{array}{c}10.39 \\
(? . ? ?)\end{array}$ & $\begin{array}{l}84.41 \\
(? . ? ?)\end{array}$ \\
\hline 12 & $\begin{array}{r}3.52 \\
(? . ? ?)\end{array}$ & $\begin{array}{c}2.43 \\
(? . ? ?)\end{array}$ & $\begin{array}{c}10.29 \\
(? . ? ?)\end{array}$ & $\begin{array}{l}83.73 \\
(? . ? ?)\end{array}$ \\
\hline 36 & $\begin{array}{r}3.54 \\
(? . ? ?)\end{array}$ & $\begin{array}{c}2.43 \\
(? . ? ?)\end{array}$ & $\begin{array}{c}10.29 \\
(? . ? ?)\end{array}$ & $\begin{array}{l}83.73 \\
(? . ? ?)\end{array}$ \\
\hline 60 & $\begin{array}{r}3.54 \\
(? . ? ?)\end{array}$ & $\begin{array}{c}2.43 \\
(? . ? ?)\end{array}$ & $\begin{array}{c}10.29 \\
(? . ? ?)\end{array}$ & $\begin{array}{l}83.73 \\
(? . ? ?)\end{array}$ \\
\hline \multicolumn{5}{|l|}{ Japan (17) } \\
\hline 1 & $\begin{array}{r}1.03 \\
(? . ? ?)\end{array}$ & $\begin{array}{c}0.23 \\
(? . ? ?)\end{array}$ & $\begin{array}{c}0.08 \\
(? . ? ?)\end{array}$ & $\begin{array}{l}98.66 \\
(? . ? ?)\end{array}$ \\
\hline 6 & $\begin{array}{r}2.94 \\
(? . ? ?)\end{array}$ & $\begin{array}{c}1.54 \\
(? . ? ?)\end{array}$ & $\begin{array}{c}2.53 \\
(? . ? ?)\end{array}$ & $\begin{array}{l}92.99 \\
(? . ? ?)\end{array}$ \\
\hline 12 & $\begin{array}{r}3.48 \\
(? . ? ?)\end{array}$ & $\begin{array}{c}2.19 \\
(? . ? ?)\end{array}$ & $\begin{array}{c}2.66 \\
(? . ? ?)\end{array}$ & $\begin{array}{l}91.67 \\
(? . ? ?)\end{array}$ \\
\hline 36 & $\begin{array}{r}3.49 \\
(? . ? ?)\end{array}$ & $\begin{array}{c}2.19 \\
(? . ? ?)\end{array}$ & $\begin{array}{c}2.67 \\
(? . ? ?)\end{array}$ & $\begin{array}{l}91.65 \\
(? . ? ?)\end{array}$ \\
\hline 60 & $\begin{array}{r}3.49 \\
(? . ? ?)\end{array}$ & $\begin{array}{c}2.19 \\
(? . ? ?)\end{array}$ & $\begin{array}{c}2.67 \\
(? . ? ?)\end{array}$ & $\begin{array}{l}91.65 \\
(? . ? ?)\end{array}$ \\
\hline \multicolumn{5}{|c|}{ United Kingdom (20) } \\
\hline 1 & $\begin{array}{r}1.55 \\
(? . ? ?)\end{array}$ & $\begin{array}{c}0.46 \\
(? . ? ?)\end{array}$ & $\begin{array}{c}0.01 \\
(? . ? ?)\end{array}$ & $\begin{array}{l}97.98 \\
(? . ? ?)\end{array}$ \\
\hline 6 & $\begin{array}{r}2.54 \\
(? . ? ?)\end{array}$ & $\begin{array}{c}2.36 \\
(? . ? ?)\end{array}$ & $\begin{array}{c}4.15 \\
(? . ? ?)\end{array}$ & $\begin{array}{l}90.95 \\
(? . ? ?)\end{array}$ \\
\hline 12 & $\begin{array}{r}3.19 \\
(? . ? ?)\end{array}$ & $\begin{array}{c}2.36 \\
(? . ? ?)\end{array}$ & $\begin{array}{l}5.17 \\
(? . ? ?)\end{array}$ & $\begin{array}{l}89.28 \\
(? . ? ?)\end{array}$ \\
\hline 36 & $\begin{array}{r}3.19 \\
(? . ? ?)\end{array}$ & $\begin{array}{c}2.37 \\
(? . ? ?)\end{array}$ & $\begin{array}{c}5.18 \\
(? . ? ?)\end{array}$ & $\begin{array}{l}89.26 \\
(? . ? ?)\end{array}$ \\
\hline 60 & $\begin{array}{r}3.19 \\
(? . ? ?)\end{array}$ & $\begin{array}{c}2.37 \\
(? . ? ?)\end{array}$ & $\begin{array}{c}5.18 \\
(? . ? ?)\end{array}$ & $\begin{array}{l}89.26 \\
(? . ? ?)\end{array}$ \\
\hline \multicolumn{5}{|l|}{ United States (22) } \\
\hline 1 & $\begin{array}{r}1.98 \\
(? . ? ?)\end{array}$ & $\begin{array}{c}0.13 \\
(? . ? ?)\end{array}$ & $\begin{array}{c}0.15 \\
(? . ? ?)\end{array}$ & $\begin{array}{l}98.24 \\
(? . ? ?)\end{array}$ \\
\hline 6 & $\begin{array}{r}2.75 \\
(? . ? ?)\end{array}$ & $\begin{array}{c}2.25 \\
(? . ? ?)\end{array}$ & $\begin{array}{c}4.75 \\
(? ? ?)\end{array}$ & $\begin{array}{l}90.25 \\
(? . ? ?)\end{array}$ \\
\hline 12 & $\begin{array}{r}4.27 \\
(? . ? ?)\end{array}$ & $\begin{array}{c}2.51 \\
(? . ? ?)\end{array}$ & $\begin{array}{c}5.33 \\
(? . ? ?)\end{array}$ & $\begin{array}{l}87.89 \\
(? . ? ?)\end{array}$ \\
\hline 36 & $\begin{array}{r}4.27 \\
(? . ? ?)\end{array}$ & $\begin{array}{c}2.52 \\
(? . ? ?)\end{array}$ & $\begin{array}{c}5.33 \\
(? . ? ?)\end{array}$ & $\begin{array}{l}87.88 \\
(? . ? ?)\end{array}$ \\
\hline 60 & $\begin{array}{r}4.27 \\
(? . ? ?)\end{array}$ & $\begin{array}{c}2.52 \\
(? . ? ?)\end{array}$ & $\begin{array}{c}5.33 \\
(? . ? ?)\end{array}$ & $\begin{array}{l}87.88 \\
(? . ? ?)\end{array}$ \\
\hline
\end{tabular}




\section{Table 4: $\quad$ Variance Decomposition Tests (Real Stock Return) (continued)}

Notes: See Table 3. Once again, the numbers in parentheses after the country name represents the number of periods until the variance decomposition reaches a constant, unchanging value for all future periods. 
Table 5: $\quad$ Temporal Causality Tests (Real Stock Return)

\begin{tabular}{lll}
\hline \multicolumn{3}{l}{ Stocks Returns (r) Temporally Caused by } \\
$\varepsilon^{\text {oss }}$ & $\varepsilon^{G D S}$ & $\varepsilon^{I D S}$ \\
\hline
\end{tabular}

Australia

$\begin{array}{lll}1.75^{*} & 1.50 & 1.59\end{array}$

Canada
0.80
0.46
0.86

France

$\begin{array}{lll}0.84 & 1.89 * & 1.58\end{array}$

Germany
0.87
0.97
$2.66^{* *}$

Italy
1.66
0.60
$4.67 * * *$

Japan
1.39
0.73
1.07

United Kingdom
0.84
0.90
$2.49 * *$

United States
1.36
1.07
$2.52 * *$

Notes: The test statistics are F-tests of the hypothesis that the lagged shocks do not significantly explain the stock-market return.

*** Significant at 1-percent level.

** $\quad$ Significant at 5-percent level.

* $\quad$ Significant at 10-percent level. 